\title{
Understanding internal conditions driving ordinary and dynamic capabilities in Indian high-tech firms
}

\author{
Sameer Qaiyum $^{\mathrm{a}}$ * and Catherine L. Wang ${ }^{\mathrm{b}}$ \\ a Liverpool Business School, Liverpool John Moores University, Redmond Building, \\ Brownlow Hill, Liverpool L3 5UG, United Kingdom \\ b Brunel Business School, Brunel University London, Kingston Lane, Uxbridge, \\ Middlesex UB8 3PH, United Kingdom
}

Accepted for publication in Journal of Business Research

\begin{abstract}
Organizational capabilities are the cornerstone of a firm's competitive advantage. However, considerable ambiguity exists on the contributions of ordinary and dynamic capabilities. This study examines the relative contributions of ordinary and dynamic capabilities to firm performance. Based on a survey of 260 Indian high-tech firms, we find that in those firms that are in early stages and the very last stage of their life cycle, ordinary capabilities outperform dynamic capabilities in improving firm performance. However, for firms in the middle two stages of their life cycle, both types of capabilities contribute equally. Similarly, for small and medium enterprises (SMEs) ordinary capabilities are more important than dynamic capabilities. However, large firms are served equally well by both types of capabilities. Our findings indicate that the role of the internal organization has been underrated in previous research that has focused primarily on the external environment to understand ordinary and dynamic capabilities contributions.
\end{abstract}

"Obsession is a young man's game" - John Cutter to Robert Angier in the movie The Prestige.

Robert, a successful magician, had already had what academicians call ordinary capabilities but was obsessed with developing new capabilities all the time, capabilities that we refer to as dynamic capabilities. The reference by John, Robert's manager, to age was a reference to a person's inner capacity to carry out ordinary and dynamic capabilities effectively. In contrast, Robert saw out- side opportunities as a determinant of ordinary and dynamic capabilities poten- tial and had little consideration for internal capacities. As the climax of the movie reveals, not listening to John's advice proved fatal for Robert. However, that was a movie, and this is research. Is there any similarity between the two? We believe there is.

\section{Introduction}

Organizational capabilities are a firm's "capacity to deploy resources, usually in combination, using organizational processes, to affect a desired end" (Amit \& Schoemaker, 1993:35) and are widely seen as the building blocks of a firm's competitive advantage (Dosi et al., 2000; Teece et al., 1997). The resource-based view (RBV) of the firm and the dynamic capabilities view (DCV) have focused on two broad categories of organizational capabilities that are essential for firm performance: zero-order ordinary capabilities needed to exploit a firm's current strategic assets through day-to-day operations (Winter, 2003) and higher-order dynamic capabilities required to alter a firm's resource base by integrating, 
building, and reconfiguring competences (Eisenhardt \& Martin, 2000; Teece et al., 1997).

Ordinary and dynamic capabilities operate on the resource base in a distinct manner and thus have a different but direct impact on firm performance (Lin \& Wu, 2014; Pezeshkan et al., 2016). Since both types of capabilities compete for the same limited resources, it is essential to understand when and under what conditions they are needed more. Scholars have mostly focused on the external conditions to understand this. For instance, it has been suggested that a dynamic environment favors dynamic capabilities (Teece, 2014) and a sta- ble environment is suited for ordinary capabilities (Vorhies et al., 2009). This research implies that outside forces dictate the fortunes of organizational capabilities. However, our understanding of what goes on inside the organization that affects ordinary and dynamic capabilities' rent potential is insufficient. Although advising managers to calibrate their organization's capabilities based on the outside environment is not wrong, it is surely inadequate. For instance, just because outside forces are favorable for dynamic capabilities does not necessarily mean that the focal organization can support dynamic capabilities. There is not always a one-to-one correspondence between outside and inside forces, and it pays to complement outside knowledge with inside knowledge (Baden-Fuller, 1995).

In this study, we seek to understand the inner capacities of organizations to support organizational capabilities, as well as how these capacities have a different impact on different types of capabilities to the extent that certain internal conditions become more favorable towards one type of capability over another. To do so, we examine the relative contributions of ordinary and dynamic capabilities to firm performance, drawing on survey data from 260 Indian high-tech firms. In particular, we focus on ordinary and dynamic capabilities through the functional lens of marketing and technology - two vital and complementary functional capabilities (Song et al., 2005), especially in high-tech firms: technological capabilities are needed for scientific inventions and translating them into concrete products, while marketing capabilities ensure that such products effectively serve the desired customers (Franco etal., 2009). Specifically, we conceptualize that ordinary capabilities consist of ordinary technological capability (i.e., a firm's ability to leverage current technologies) and ordinary marketing capability (i.e., a firm's ability to serve existing markets); dynamic capabilities consist of dynamic technological capability (i.e., a firm's ability to identify and adopt new technologies) and dynamic marketing capability (i.e., a firm's ability to detect and enter markets previously unserved) (Danneels, 2009). This conceptualization is in line with recent calls to study organizational capabilities in their specific functional domains (Pezeshkan et al., 2016).

We aim to contribute to the strategic management research, in particular the organizational capabilities literature, by building a theory on internal conditions that support ordinary and dynamic capabilities. More importantly, our study also helps to solve the dilemma faced by practitioners in allocating resources to develop organizational capabilities. Both ordinary and dynamic capabilities directly compete for limited organizational resources (Ambrosini \& Bowman, 
2009). By delineating the internal conditions that equally favor both types of capabilities or favor one type more than the other, we intend to solve managers' dilemma of resource allocation. Our findings will provide practical guidance for managers to make informed decisions on their commitment to developing ordinary and dynamic capabilities under different internal conditions.

\section{Theory and Hypotheses}

Ordinary capabilities exploit the existing resource base to ensure continuity of current operations. Dynamic capabilities, on the other hand, alter the resource base to allow firms to explore beyond their current market and technological domains. The organizational ambidexterity literature suggests that both exploitation and exploration are equally important. Moreover, those firms that do not give equal weight to both will suffer in the long run (Raisch \& Birkinshaw, 2008). Consequently, firms need to maintain the same level of proficiency in both ordinary and dynamic capabilities to survive. In contrast, the punctuated equilibrium literature posits that as long as firms face a stable competitive environment, they need to exploit more than explore. However, radical changes in the competitive environment force firms to explore more, for a short burst of time, before moving back to the status quo (Sarkees et al., 2010). Therefore, the weight of both ordinary and dynamic capabilities changes with a changein the outside environment. That a firm does not necessarily need both ordinary and dynamic capabilities equally all the time also has a parallel in the organizational capabilities literature. The empirical findings in this literature suggest that ordinary capabilities are more vital in a stable environment and dynamic capabilities in a more turbulent environment (Drnevich \& Kriauciunas, 2011).

The current study predicts the relative importance of ordinary and dynamic capabilities by relying on an outside-in perspective. That is, it is the outside environment that forces the firm to use one type of capabilities more than the other. While the importance of environment can never be underestimated, the outside-in perspective overlooks the internal condition that favors the use of one type of capability more than the other. We take a firm perspective to understand when and why the relative importance of ordinary and dynamic capabilities keep changing. Complementing the market perspective with firm perspective is the ultimate challenge of strategic management research (Chen \& Miller, 2012). We use information processing theory to do so.

Information processing theory posits that a firm's behavior can be explained by examining the flow of information in and around the firm (Thompson, 1967; Tushman \& Nadler, 1978). Information processing in an organization entails data gathering and its transfer from those who are at the forefront of the market within the organization and have a more accurate picture of the environment, to the middle and top managers to help them make strategic decisions regarding the organization (Smith et al., 1991). The information processing theory explains the different phenomenon ranging from strategy to structure, decision making, and competitive moves (Dibrell \& Miller, 2002). In this paper, we study how information processing capacity changes with the 'organizational life cycle' and 
'firm size' to understand the relative performance of ordinary and dynamic capabilities.

\subsection{Information processing and organizational life cycle}

Ordinary and dynamic capabilities have different underpinnings. Ordinary capabilities are more rooted in routines than dynamic capabilities (Teece, 2012). Routines refer to both behavior and cognitive regulation that results in recurring interaction patterns and rules respectively (Nelson, 2009). How an organization will serve its current market will have both behavioral and cognitive regulation about it. Dynamic capabilities, on the other hand, are ingrained in 'creative managerial and entrepreneurial acts', acts that by their nature are strategic and non-routine (Teece, 2012). For instance, creating new markets is a strate- gic act, which might be guided by some underlying principles of 'what to do when entering new markets', is primarily based on the judgment and skills of managers. Dynamic capabilities of any form signify change, and change is itself never wholly routinized (Pentland et al., 2012). It is entrepreneurial and leadership skills, in other words, that are required to sustain dynamic capabilities (Hodgson, 2012). However, this is not to suggest that dynamic capabilities are completely devoid of routines. While (Teece, 2012) argues that there may be some underlying principles that guide dynamic capabilities, without a doubt ordinary capabilities are far more routinized than dynamic capabilities (Winter, 2003).

The information processing theory posits that the nonroutine nature of a task increases uncertainty (Dibrell \& Miller, 2002). Uncertainty is defined as "the difference between the amount of information required to perform the task and the amount of information already possessed by the organization" (Galbraith, 1973:5). Galbraith (1973:4) argues that "the greater the task uncertainty, the greater the amount of information that must be processed among decision makers during task execution in order to achieve a given level of performance". The amount of information required to manage current technology will always be less than the information required to grasp new technologies. For instance, in a study of the match between technology and amount of information processing in R\&D project groups, Keller (1994) finds that nonroutine technology requires high information processing to achieve project quality. This suggests that ordinary and dynamic capabilities differ in their information processing requirements. The later requires higher information processing than the former.

How do organizations go about increasing their information processing capacity that can support dynamic capabilities well? Organizational theorists have long proposed that the information processing capacity of firms changes with the organization life cycle stage (Lester et al., 2003). The organization life cycle is a theoretical notion that organizations progress through various life cycle stages as they are born, grow and eventually die. These stages are a unique configuration of variables related to organization context, strategy, and structure (Hanks et al., 1994). More importantly, for this research, information processing becomes simple and complex depending on the life cycle stages. Although scholars differ on the number of stages an organization follows over the 
course of its life, the five-stage model is by far the most accepted model (Lester et al., 2003). Moreover, it is the five-stage model (start-up, accelerated growth, steady growth, stability, and decline) that we adopt in this study.

Simpleinformation processing characterizes the first two stages (start-up and accelerated growth) of the life cycle (Lester et al., 2003). However, as organizations enter the next two stages (steady growth and stability) they develop more information processing procedures (Lester et al., 2003), such as "sophisticated information systems, formal and performance controls, scanning activities, planning procedures and communication systems (Aguilar 1967; Galbraith 1973)." (Miller \& Friesen, 1984:1164). The last stage of the life cycle (decline) sees a reverse in the situation as an organization reverts back to simpler information processing (Lester et al., 2003). Thus, the early two stages (start-up and accelerated growth) and the last stage (decline) have simpler information processing procedures compared to the middle two stages (steady growth and stability). We posit that this, in turn, also has a profound impact on organizations' capacity to support ordinary and dynamic capabilities.

Life cycle stages that are characterized by low information processing are suited for ordinary capabilities and apparently not for dynamic capabilities. In contrast, life cycle stages that are characterized by high information processing procedures can support dynamic capabilities and ordinary capabilities; although ordinary capabilities require a low amount of information processing, high information processing doesnotimpedetheirfunctioning. Therefore, wehypothesize:

H1: In firms that are in the first two stages (start-up and accelerated growth) and the last stage (decline) of the life cycle, ordinary capabilities will outperform dynamic capabilities regarding firm performance.

H2: In firms that are in middle two stages (steady growth and stability) of the life cycle, both ordinary and dynamic capabilities will do equally well as it relates to firm performance.

\subsection{Information processing and firm size}

Information processing differences between ordinary and dynamic capabilities arise not only because of routines or lack of routines; ordinary and dynamic capabilities also differ on the amount of search activities associated with both (Danneels, 2002). These search activities involve gathering and filtering information about technology and market that can be passed on to those within the organization who can make sense of it and eventually act on it (March \& Simon, 1958). In the ordinary capabilities case, this search is mostly 'local' within the vicinity of existing technologies and markets. However, dynamic capabilities involve more 'distant' search to explore new technologies and markets (Zollo \& Winter, 2002).

Organizations require resources to facilitate search, which incurs a cost (March \& Simon, 1958). Although both local and distant search involves some 
cost, the distant search is costlier than local search. As Teece (2007:1322) notes, "overcoming a narrow search horizon is extremely difficult and costly for management teams tied to established problem-solving competences." Researchers have previously addressed the issue of 'resources needed for search' through the concept of organization slack (Smith et al., 1991). Slack is a cushion of actual or potential resources that allows an organization to adapt successfully to internal and external pressures for change (Bourgeois, 1981). Slack provides resources for firms to look beyond their current operations and search for new opportunities (Cyert \& March, 1963). Moreover, organizations with slack resources can afford sophisticated search activities to enhance their search processes. Furthermore, firms with ample slack resources are more able to implement responses. For example, such firms may divert regular staff from their routine work for the development and maintenance of dynamic capabilities (Ambrosini \& Bowman, 2009).

Firm size is closely associated with organizational slack. Small and mediumsized enterprises (SMEs) do not have the resource endowment to build a large stock of slack resources (Sirmon et al., 2007). Whatever we have discussed so far about search and slack suggests that lack of adequate slack will impede SMEs' ability to support dynamic capabilities. However, this in no way suggests that SMEs lack entrepreneurial nature. In fact, they might be more driven by hunger and engage in distant search without much consideration of (limited) resources currently controlled. However, there can be little doubt that for SMEs, any advantage of dynamic capabilities would be offset by cost incurred due to regular distant search. This might have lead Helfat \& Winter (2011) to advise SMEs to avoid the overhead burdens of dynamic capabilities, despite their value, and instead fuel their growth via other means, such as ad hoc problem solving that requires infrequent distant search as opposed to more regular distant search associated with dynamic capabilities. Therefore, we hypothesize:

H3: In SMEs, ordinary capabilities will outperform dynamic capabilities regarding firm performance.

In contrast to SMEs, large firms have enough slack resources to support distant search along with more local search. Slack allows large firms to experiment with new technologies and enter new markets (Thompson, 1967). For instance, the deployment of dynamic capabilities often entails diverting regular staff from their routine work and getting them to work on new technologies and new markets. This involves opportunity costs that slack can absorb (Ambrosini \& Bowman, 2009). This does not necessarily make large firms more entrepreneurial. In fact, firms with a higher level of slack can often becomplacent about external environment demands (Litschert \& Bonham, 1978) and at times show limited inclination to experiment (Sinclair et al., 2000). However, the presence of higher level of slack ensures that large firms can absorb the cost of the distant search. Thus, large firms support both ordinary and dynamic capabilities well. Therefore, we hypothesize: 
H4: In large firms, both ordinary and dynamic capabilities will do equally well regarding firm performance.

\section{Method}

\subsection{Sample and data}

This study employed survey data from Indian high-tech firms sincehigh-tech firms are more likely to display both ordinary and dynamic capabilities than non-high-tech firms (Teece et al., 1997). A substantial portion of India's growth is propelled by its high-tech sectors, compared with other emerging economies. However, the sustainability of India's growth has been questioned, and India has been sliding in the global competitiveness rankings (Porter et al., 2012). While India performs better in innovation and business sophistication, it lacks the most basic drivers of competitiveness, such as institutions, infrastructure, and macroeconomic environment (Porter et al., 2012), which pose challenges to high-tech firms' sustained growth. Hence, Indian high-tech firms provide a relevant context for us to study the effects of ordinary and dynamic capabilities on firm performance within the environmental context.

We selected three industry sectors: biotechnology, electronics, and information technology (IT), classified as high-tech sectors by the Organisation for Economic Cooperation and Development (OECD, 1999). IT industry has been widely credited for fueling India's growth in the nontraditional sector. The contribution of the IT industry to Indian GDP stands at 5.8\%, and it is the major exporting sector and employs more than 2 million people (Goldberg et al., 2010). The biotechnology sector is a highly innovative and dynamic industry and is a key source of high-skill, high-tech jobs (Department of Business Innovation \& Skills., 2011). India is not only among the top 12 biotech destinations in the world but also has the second-highest number of US Food and Drug Administration (USFDA) approved biotech manufacturing plants. The Indian biotech sector is valued at 11 billion dollars and has shown a remarkable growth rate of 20 percent (India Brand Equity Foundation, 2017). The electronics sector ranks highly among the various industries that defied recession and contributed immensely to the Indian economy. This sector is very dynamic in India as it depends on adoption of new technologies, catalyzing innovation, entrepreneurship, and enhancement of skills for much of its growth (ISA - FROST \& SULLIVAN, 2011).

India presents many of the challenges for sampling and data collection as discussed by Kriauciunas et al. (2011): most firms are privately held; detailed and dependable information on firms is not readily available, and industries are dynamic with emerging players. Consequently, a variety of data sources such as online databases, industry association lists or online and print directories must be used (Kriauciunas et al., 2011). We obtained (a) a list of electronics and information technology firms that were members of their apex tradeassociations, containing the email of a contact person (usually a top manager or a business 
owner) in each firm; and (b) a list of biotechnology firms that were members of a biotechnology organization that was publicly available. We then obtained the email address of a contact person at each biotechnology firm by visiting their websites and calling them directly. Our final list consisted of 3,186 high-tech firms of the three industries.

We conducted a web survey using Qualtrics to collect detailed data on firms' capabilities and other characteristics. Following Dillman's (2007) total design method for mail and internet survey, we conducted the web survey in five phases. First, we emailed the named contacts in all of the 3,186 firms, to introduce the research team, the objectives, and significance of the study, and the reason why their firms were chosen, the incentives for participants, confidentiality, and research ethics, and the link to the web survey. This was followed by four reminder emails to nonresponders. In total, 289 responses were received (a 9.1\% total response rate), including 260 usable responses (an 8.2\% effective response rate). This rate is comparable to that of other studies directed at top managers or business owners (Ling et al., 2008). Respondents primarily included top managers (e.g., CEOs, founders, owners, partners, chairpersons, and managing directors) and senior executives in the major business functions. Respondents had, on average, 9.3 years of experience with their respective firms, and 18.7 years of expertise in the industries in which their firms operated. This provided evidence of the respondents' knowledge and competence to report on their firms and the environment. Table 1 summarizes the sample profile.

\section{INSERT TABLE 1 ABOUT HERE}

We tested nonresponse bias, first by comparing the differences in the key variables between early and late respondents (the first third vs the last third of respondents) (Armstrong \& Overton, 1977). Significant differences werefound in only one of the 26 variables $(\mathrm{p}<0.05)$, suggesting that nonresponse bias is not a significant concern. Second, we examined whether the nonresponding firms differed from the responding firms regarding firm size and age and found no significant differences ( $p>0.05)$.

To control for common method bias, we employed procedural and statistical methods. First, we assured respondents of strict anonymity and confidentiality in the emails and the front page of the survey and encouraged them to answer the questions as honestly as possible. This technique decreases respondents' tendency to make socially desirable responses or be compliant in their responses (Podsakoff et al., 2003). Second, to reduce item ambiguity, we carefully avoided double meaning questions and vague concepts and kept questions as simple as possible (Tourangeau et al., 2000). Third, we performed Harman's one- factor test (Podsakoff \& Organ, 1986), by including all the study variables in an exploratory factor analysis. No general factor emerged in the unrotated factor structure, and the first factor accounted for only $32.90 \%$ of the variance. Fourth, we controlled for an unmeasured latent common method (Mihalache et al., 2012; Podsakoff et al., 2003) by following the PLS adaption technique 
(Liang et al., 2007) and found no significant bias. This suggests that common method bias was not a problem. Finally, we gathered information from a second respondent in a total of 26 firms (10\% of the sample). We first calculated rWG - the most common index of inter-rater agreement (LeBreton \& Senter, 2008). The average rWG of all the seven constructs ranged from 0.75 to 0.90 , and median rWG from 0.89 to 0.97 , indicating satisfactory agreement (LeBreton \& Senter, 2008). Next, we calculated the intraclass correlations, ICC (1), which provides a measure of response convergence. For all the seven constructs, we obtained ICC (1) exceeding Bliese's (1998) 0.1 cut-off. Both rWG and ICC (1) results indicate that single respondent bias was not a problem.

\subsection{Measurement}

We used established measures to increase the validity of the constructs. Table 2 summarizes the constructs. Independent variables: Ordinary and dynamic capabilities were conceptualized as second-order formative constructs, following Anderson et al.'s (2014) guidelines: the indicators of the formative construct are distinct and not interchangeable and may have a different set of antecedents and consequences, all of which apply to first-order marketing and technological capabilities. Danneels' (2012) scales are adapted to measure each of the four first-order constructs: ordinary technological capability captured a firm's ability to produce a product or service for its existing customers; ordinary marketing capability assessed a firm's ability to serve a particular group of existing customers; dynamic technological capability assessed a firm's ability to identify and adopt new technologies; and dynamic marketing capability assessed a firm's ability to detect and penetrate previously unserved markets.

\section{INSERT TABLE 2 ABOUT HERE}

Dependent variable: Firm performanceis a second-orderformative construct for the same reason as the one outlined above consisting of firm efficiency and growth. Firm efficiency and growth are measured using Auh \& Menguc's (2005) scales: firm efficiency encompassed such items as return on assets, income, sales, and profitability, while firm growth captures growth in sales and market share. For each item, we assess the responding firm's level of satisfaction with own performance compared with that of its competitors.

Moderating and control variables: Consistent with previous research (e.g., Lumpkin \& Dess (1995)), respondents were asked to identify the variable that best described the current stage of their organizations' development. Following Lumpkin \& Dess (1995) and Lester et al. (2003), choices for this itemincluded start-up, accelerated growth, steady growth, stability, and decline. Environmental turbulence is assessed using five items from Atuahene-Gima (2005), encompassing the pace of change in technology, customers, and competitors. Firm size is measured as the number of employees (Schilke, 2014). Firm age andindustry type are also included as control variables since firm age can predict 
performance (Zhou \& Wu, 2010) and industry type can also affect firm performance (Wang et al., 2015). Firm age is measured as the natural logarithm of years since inception until 2015 .

Confirmatory factor analysis of the measurement model was performed to test first-order factors. Items were dropped to remove cross-loading when necessary to ensure their unidimensionality, and the expected pattern of seven firstorder factors emerged (Table 2): ordinary and dynamic marketing capabilities, ordinary and dynamic technological capabilities, firm efficiency and growth, and environmental turbulence. Table 3 shows that all the first-order constructs are satisfactory, providing evidence of their reliability, convergent, and discriminant validity. Since reliability and convergent validity of formative constructs cannot be assessed in the same way as reflective constructs (Hulland, 1999), secondorder formative constructs are tested for multicollinearity based on variance inflation factors (VIFs) among their respective first-order constructs, using procedures suggested by Diamantopoulos \& Winklhofer (2001). The VIF values are well below the threshold criterion of 10 , proving that there is no excessive multicollinearity between the first-order constructs. This suggests that the first-order constructs are rightly tapping into different dimensions of formative constructs (Petter et al., 2007).

INSERT TABLE 3 ABOUT HERE

\section{Findings}

We employed PLS structural equation modeling (SEM) using SmartPLS (Ringle et al., 2005). PLS is increasingly being used in strategy research (e.g., (Ciabuschi et al., 2011; Gruber et al., 2010) to handle second-order constructs (Chin \& Newsted, 1999), as it avoids both factor indeterminacy and inadmissible solutions (Vinet \& Zhedanov, 2010). We first applied the PLS algorithm followed by the bootstrapping procedure with 1,000 subsamples to test for statistical significance of the base model $(n=260)$. The coefficient of determination R2 is used for evaluation purposes as there are no overall goodness-of-fit statistics for a PLS model (Hulland, 1999). Figure 1 presents the best fit between the data and the base model that explained $33.5 \%$ of the variance in firm performance. The variance explained is in line with similar studies(Trichterborn et al., 2015).

\section{INSERTFIGURE 1 ABOUT HERE}

H1 posits that in firms that are in the first two stages (start-up and accelerated growth) and the last stage (decline) of the life cycle, ordinary capabilities will outperform dynamic capabilities in terms of firm performance. For firms 
in the first two stages and the last stage $(n=95)$, the path coefficient of ordinary capabilities on firm performance $(\beta=0.60, p<0.05)$ is much stronger than that of dynamic capabilities on firm performance $(\beta=-0.04, p>0.05)$. To test whether the difference in path coefficients is statistically significant, we calculated the bias-corrected confidence intervals (Cumming, 2009) around the path coefficients of ordinary and dynamic capabilities. If the confidence intervals overlap by less than $50 \%$, then the path coefficients are considered significantly different from each other $(\mathrm{p}<0.05)$. In this case, the confidence intervals do not overlap by more than $50 \%$, showing that path coefficients are indeed significantly different from each other $(\mathrm{p}<0.05)$.

$\mathrm{H} 2$ posits that both ordinary and dynamic capabilities have an equal effect on firm performance in firms that are in the middle two stages (steady growth and stability) of the life cycle. The results indicate that in the middle two stages $(n=165)$ the path coefficient of ordinary capabilities $(\beta=0.31, p<0.05)$ is almost equal to that of dynamic capabilities $(\beta=0.33, \mathrm{p}<0.01)$ on firm performance. The confidence intervals do not overlap by less than $50 \%$, providing statistical evidencethat the path coefficients are indeed not significantly different from each other $(\mathrm{p}<0.05)$. Hence, $\mathrm{H} 2$ is supported, and ordinary and dynamic capabilities have an equal impact in the middle two stages.

Totest the relative contributions of ordinary and dynamic capabilities to firm performance in SMEs and large firms, we split the scores of firm size in terms of the number of employees into SMEs with less than 250 employees $(n=171)$ and large firms with 250 or more employees $(n=89)$. Traditionally, the official classification of SMEs by the Indian government has relied on total capital investment in plant and equipment, but this definition is problematic for hightech sectors for several reasons. First, high-tech sectors are knowledge-based and are mainly dependent on human resources for creating value as opposed to capital resources and investment (Barney, 1991). Second, high-tech sectors in India have developed mainly independently of government support and are very different in their functioning than traditional capital incentive sectors in India (Brown, 2013). In fact, they are closer to peers in the same sectors outside India than peers from traditional sectors in India (Upadhya \& Vasavi, 2006). It is for these reasons that we have relied on a universal approach to classify high-tech SMEs based on their number of employees.

$\mathrm{H}_{3}$ posits that ordinary capabilities have a stronger effect on firm performance than dynamic capabilities do in SMEs. The results show that in SMEs the path coefficient of ordinary capabilities $(\beta=0.41, p<0.01)$ is stronger than that of dynamic capabilities $(\beta=0.19, p>0.05)$ on firm performance. The confidence intervals overlap by less than $50 \%$, showing that path coefficients differ significantly from each other $(\mathrm{p}<0.05)$. Hence, $\mathrm{H}_{3}$ is supported. Hypothesis 4 posits that both dynamic and ordinary capabilities have an equal effect on firm performance in large firms. Consistent with the prediction, in large firms the path coefficient of ordinary capabilities $(\beta=0.31, \mathrm{p}<0.05)$ is almost equal to that of dynamic capabilities $(\beta=0.27, \mathrm{p}<0.05)$ on firm performance. The confidence intervals overlap by more than $50 \%$, showing that path coefficients are indeed not significantly different from each other ( $p>0.05)$. Hence, $\mathrm{H}_{4}$ is supported, 
and dynamic and ordinary capabilities perform equally well in large firms.

\section{Discussion}

The origins of organizational capabilities literature are in the inside-out approach that seeks to locate the source of profitability inside the firm (Helfat \& Winter, 2011). However, despite its origin, the organizational capabilities literature has almost exclusively relied on the 'external environment' to predict the rent potential of organizational capabilities (Li \& Liu, 2014). For instance, Teece et al. (1997:516) argue that "The term 'dynamic' (in dynamic capabilities) refers to the capacity to renew competences to achieve congruence with the changing business environment". Eisenhardt \& Martin (2000), often seen as being in disagreement with Teece and colleagues, seem to agree on the following point: "the pattern of effective dynamic capabilities depends upon market dynamism" (p. 1110). Similarly, ordinary capabilities are also propositioned to follow the congruence framework (Karna et al., 2016), that is, that the environment plays a role in determining ordinary capabilities performance. However, the empirical findings do not always support this framework (e.g., Drnevich \& Kriauciunas (2011); Pezeshkan et al. (2016)).

Our findings suggest that this discrepancy in empirical and conceptual literature might be due to the neglect of internal dynamism. The current literature, by and large, pays little attention to the internal capacity of an organization to support organizational capabilities. Being fixated on outside forces, the literature just assumes that organizations have what it takes to support organizational capabilities all the time. However, this is definitely not the case. Our findings show that ordinary and dynamic capabilities relative significance changes with organizations' information processing capacity. However, we do not interpret our results as the dismissal of congruence framework. In fact, our results complement it. Our findings suggest that just because a dynamic environment favors dynamic capabilities does not necessarily mean that firms have the information processing capacity to support them. Similarly, the environment may be hostile to dynamic capabilities, but the information processing capacity of the focal firm might be perfectly aligned with that needs of dynamic capabilities. As a result, dynamic capabilities will prosper, although the congruence framework predicts that they should not. Therefore, a more nuanced approach that takes into consideration both outside and inside forces is best to predict the scope of organizational capabilities.

Second, our contribution lies in bringing to the fore the information processing characteristics of organizational capabilities routines. Currently, ample space is given to study the routine nature of organizational capabilities (Teece, 2012; Winter, 2003). However, this discussion is mostly confined to the flexibility and rigidity dilemma that routines provide (Pentland et al., 2012). For instance, ordinary capabilities are the antithesis to change, mainly owing to the rigidity of their constituting routines. Dynamic capabilities, on the other hand, are mostly free from rigid routines and facilitate change (Teece, 2012). We further add to this discussion by noting that although routines might create rigid- 
ity, they also solve information processing problems. Because of their routine nature, ordinary capabilities require less information processing than dynamic capabilities. As a result, they can prosper even when organizations have less developed capacity to process information. Moreover, this phenomenon is best exemplified in various stages of the organization life cycle that differ in their information processing capacities. The early and last stages of the organization life cycle have less information processing capacity and hence support less demanding ordinary capabilities more than dynamic capabilities. Because of their high information processing capacities, the middle two stages can support the demands of both types of capabilities.

Lastly, we contribute by developing the implications of costs associated with organizational capabilities. Costs are discussed at least in dynamic capabilities literature. Dynamic capabilities are costly (Zahra et al., 2006). However, beyond that, the nature of cost structure and its implications are never developed in detail. We develop the cost implications of organizational capabilities by explicitly focusing on the costs associated with information processing search. Information seeking search can be costly, especially if it takes place in the periphery of organizational boundaries rather than within them. Moreover, because dynamic capabilities mainly entail searching beyond current technological and market boundaries, they are costlier than more local search associated with ordinary capabilities. Large organizations rather than small ones have the slack to support the additional costs associated with the distant search of dynamic capabilities.

\section{Implications for managers}

We began with the advice of John Cutter to Robert Angier and the questions it raised. Robert believed in developing capabilities based on external demand. There is a plethora of academic articles that seek to establish the importance of external context in determining the importance of both ordinary and dynamic capabilities. However, John had advice for Robert: first, establish whether you have the capacity to develop and maintain capabilities. Hardly any research has sought to understand the role of internal capacities of an organization to support ordinary and dynamic capabilities. Therein lies in the importance of our research. Our finding confirms that John was right in pointing toward internal capacities. Without understanding the merits of internal capacities first, managers may end up making less than optimum decisions on organizational capabilities.

Based on our findings, we recommend that managers should feel the pulse of their organization before they decide to develop and deploy dynamic capabilities. Distinct stages of the life cycle come with their own information processing capacities. Those organizations that are in the initial stages or are at their dying stage will do best by avoiding dynamic capabilities and instead concentrating on their ordinary capabilities. Similarly, managers of small organizations might have heard a lot about virtues of dynamic capabilities in their MBA days. However, they should be aware that their small size comes with some constraints, 
especially the lack of freely available resources. Moreover, dynamic capabilities require considerable such resources. If they do decide to develop and deploy dynamic capabilities, they might find that they are being forced to starve ordinary capabilities to fuel dynamic capabilities. This is not the best of scenario considering the ordinary capabilities are the bread and butter of most organizations.

Finally, are we suggesting to managers of small organizations and those whose organizations might be in the early or declining stage of their life cycle to not innovate, experiment or be ambitious enough to grow outside their existing boundaries? No, we are not. In fact, we suggest that they do all that and more but instead depend on substitutes that might not demand a permanent increase in information processing. Ad hoc problem solving is one of them. High information processing, but for short burst of time, is another. They should then revert to low information processing that these organizations can comfortably afford. For managers of large organizations and those that are entering the middle stages of their life cycle and have developed sophisticated information processing systems, we have only one suggestion: both ordinary capabilities and dynamic capabilities can and should be supported equally.

\section{Limitations, and future research}

Our study has several limitations but also reveals opportunities for future research. First, our findings of the understated contribution of dynamic capabilities imply that ad hoc problem solving may well be used as an alternative to address changes in the environment (Winter, 2003). Future studies could directly examine ad hoc problem solving as an alternative to ordinary and dynamic capabilities. Second, the effect of dynamic capabilities is more pronounced in the long run (O'Reilly \& Tushman, 2008), which cannot be tested in our crosssectional data. Future research may collect longitudinal data to look at the longterm performance effects of ordinary and dynamic capabilities. Finally, we focus on the ordinary and dynamic variants of marketing and technological capabilities as a subset of organizational capabilities. While these capabilities are prominent in high-tech firms, future research may examine other business functions that are most relevant and specific to the nature of the sample firms.

\section{References}

Ambrosini, V., \& Bowman, C. (2009). What are dynamic capabilities and are they a useful construct in strategic management? International Journal of Management Reviews, 11 , 29-49. doi:10.1111/j.1468-2370.2008.00251.x. arXiv:arXiv:1011.1669v3.

Amit, R., \& Schoemaker, P. J. H. (1993). Strategic Assets and Organizational Rent. Strategic Management Journal , 14 , 33-46. 
Anderson, B. S., Kreiser, P. M., Kuratko, D. F., Hornsby, J. S., \& Eshima, Y. (2014). Reconceptualizing entrepreneurial orientation. Strategic Management Journal , 36 , 1579-1596.

Armstrong, J. S., \& Overton, T. S. (1977). Estimating Nonresponse Bias in Mail Surveys. Journal of Marketing Research, 14 , 396. doi:10.2307/3150783. arXiv:arXiv:1011.1669v3.

Atuahene-Gima, K. (2005). Resolving the Capability-Rigidity Paradox Innovation in New Product. Journal of Marketing, 69, 61-83.

Auh, S., \& Menguc, B. (2005). Balancing exploration and exploitation: The moderating role of competitive intensity. Journal of Business Research, 58, 1652-1661. doi:10.1016/j.jbusres.2004.11.007.

Baden-Fuller, C. (1995). Strategic Innovation, Corporate Entrepreneurship and Matching Outside-in to Inside-out Approaches to Strategy Research. doi:10. 1111/j.1467-8551.1995.tb00134.x.

Barney, J. B. (1991). Firm Resources and Sustained Competitive Advantage. Journal of Management , 17 , 99-129.

Bourgeois, L. J. (1981). On the Measurement of Organizational Slack1. The Academy of Management Review , 6, 29-39.

Brown, M. (2013). India 2.0. The Telegraph, .

Chen, M.-j., \& Miller, D. (2012). Competitive Dynamics: Themes, Trends, and a Prospective Research Platform Ming-Jer. Academy of Management Annals, 6 , $1-83$.

Chin, W. W., \& Newsted, P. R. (1999). Statistical Strategies for Small Sample Research. In R. Hoyle (Ed.), Statistical Strategies for Small Sample Research chapter Structural. (pp. 307-341). Thousand Oaks, California: Sage Publications.

Ciabuschi, F., Dellestrand, H., \& Mart'm, O. M. (2011). Internal embeddedness, headquarters involvement, and innovation importance in multinational enterprises. Journal of Management Studies, 48 , 1612-1639. doi:10.1111/j. 1467-6486.2011.01014.x.

Cumming, G. (2009). Inference by eye: Reading the overlap of independent confidence intervals. Statistics in Medicine, 28, 205-220.

Cyert, R. M., \& March, J. G. (1963). A behavioral theory of the firm. Englewood Cliffs, NJ.

Danneels, E. (2002). The dynamics of product innovation and firm competences. Strategic Management Journal , 23 , 1095-1121. doi:10.1002/smj.275. 
Danneels, E. (2009). Second-order competences and Schumpeterian rents. Strategic Entrepreneurship Journal , 6, 42-58.

Danneels, E. (2012). Second-order competences and Schumpeterian rents. Strategic Management Journal , 6, 42-58.

Department of Business Innovation \& Skills. (2011). Strategy for UK Life Sciences. Technical Report.

Diamantopoulos, A., \& Winklhofer, H. M. (2001). Index Construction with Formative Indicators: An Alternative to Scale Development. Journal of Marketing Research, 38 , 269-277.

Dibrell, C., \& Miller, T. R. (2002). Organization design: the continuing influence of information technology. Management Decision, 40 , 620-627. doi:10.1108/ 00251740210434016.

Dillman, D. (2007). Mail and Internet Surveys: the tailored design method . (2nd ed.). Hoboken: John Wiley and Sons.

Dosi, G., Nelson, R., \& Winter, S. (2000). The nature and dynamics of organizational capabilities. Oxford university press. doi:10.1093/0199248540.001. 0001.

Drnevich, P. L., \& Kriauciunas, A. P. (2011). Clarifying the conditions and limits of the contributions of ordinary and dynamic capabilities to relative firm performance. Strategic Management Journal , 32 , 254-279.

Eisenhardt, K., \& Martin, J. (2000). Dynamic Capabilities: What are They? Strategic Management Journal , 21 , 1105-1121.

Franco, A. M., Sarkar, M., Agarwal, R., \& Echambadi, R. (2009). Swift and Smart: The Moderating Effects of Technological Capabilities on the Market Pioneering-Firm Survival Relationship. Management Science, 55, 1842-1860. doi:10.1287/mnsc.1090.1061.

Galbraith, J. R. (1973). Designing complex organizations . Reading, MA: AddisonWesley.

Goldberg, P. K., Khandelwal, A. K., Pavcnik, N., \& Topalova, P. (2010). Imported Intermediate Inputs and Domestic Product Growth: Evidence from India. The Quarterly Journal of Economics, 125, 1727-1767. doi:10.1162/ qjec.2010.125.4.1727.

Gruber, M., Heinemann, F., Brettel, M., \& Hungeling, S. (2010). Configurations of resources and capabilities and their performance implications: an exploratory study on technology ventures. Strategic Management Journal , 31 , $1337-1356$. 
Hanks, S. H., Watson, C. J., Jansen, E., \& Chandler, G. N. (1994). Tight- ening the Life-Cycle Construct: A Taxonomic Study of Growth Stage Configurations in High-Technology Organizations. Entrepreneurship Theory and Practice, $18,5^{-29}$.

Helfat, C. E., \& Winter, S. G. (2011). Untangling Dynamic and Operational Capabilities: Strategy for the (N)ever-Changing World. Strategic Management Journal , 32 , 1243-1250.

Hodgson, G. M. (2012). The Mirage of Microfoundations. Journal of Management Studies, 49 , 1389-1394. doi:10.1111/j.1467-6486.2012.01079.x.

Hulland, J. (1999). Use of Partial Least Squares (PLS) in Strategic Management Research: A Review of Four Recent Studies. Strategic Management Journal , 20 , 195-204.

India Brand Equity Foundation (2017). Biotechnology industry in India. URL: https://www.ibef.org/industry/biotechnology-india.aspx.

ISA - FROST \& SULLIVAN (2011). India Semiconductor Market Update. Technical Report India Semiconductor Association.

Karna, A., Richter, A., \& Riesenkampff, E. (2016). Revisiting the role of the environment in the capabilities-financial performance relationship: A metaanalysis. Strategic Management Journal , 37 , 1154-1173.

Keller, R. T. (1994). Technology-Information Processing Fit and the Performance of R\&D Project Groups: A Test of Contingency Theory. Academy of Management Journal , 37 , 167-179. doi:10.2307/256775.

Kriauciunas, A., Parmigiani, A., \& Rivera-Santos, M. (2011). Leaving our comfort zone: Integrating established practices with unique adaptations to conduct survey-based strategy research in nontraditional contexts. Strategic Management Journal , 32 , 994-1010.

LeBreton, J. M., \& Senter, J. L. (2008). Answers to twenty questions about interrater reliability and interrater agreement. Organ Res Methods, 11 , 815852. doi:10.1177/1094428106296642.

Lester, D. L., Parnell, J. A., \& Carraher, S. (2003). Organizational Life Cycle: a Five-Stage Empirical Scale. The International Journal of Organizational Analysis, 11 , 339-354. doi:10.1108/eb028979. arXiv:ISSN 1055-3185.

Li, D., \& Liu, J. (2014). Dynamic capabilities, environmental dynamism, and competitive advantage: Evidence from China. Journal of Business Research, 67 , 2793-2799. doi:10.1016/j.jbusres.2012.08.007.

Liang, H., Saraf, N., Hu, Q., \& Xue, Y. (2007). Assimilation of Enterprise Systems: The Effect of Institutional Pressures and the Mediating Role of Top Management. MIS Quarterly, 31 , 59-87. doi:10.2307/25148781. 
Lin, Y., \& Wu, L. Y. (2014). Exploring the role of dynamic capabilities in firm performance under the resource-based view framework. Journal of Business Research, 67 , 407-413. doi:10.1016/j.jbusres.2012.12.019.

Ling, Y. a. N., Simsek, Z., Lubatkin, M. H., \& Veiga, J. F. (2008). Transformational Leadership's Role in Promoting Corporate Entrepreneurship: Examining the CEO-TMT Interface. Academy of Management Journal , 51 , 557-576. doi:10.2307/20159526. arXiv:8.

Litschert, R. J., \& Bonham, T. W. (1978). A Conceptual Model of Strategy Formation. Academy of Management Review , 3 , 211.

Lumpkin, G. T., \& Dess, G. G. (1995). Simplicity as a Strategy-Making Process: The Effects of Stage of Organizational Development and Environment on Performance. The Academy of Management Journal , 38 , 1386-1407.

March, J., \& Simon, H. (1958). Organizations. (First edit ed.). Wiley.

Mihalache, O. R., Jansen, J.J., Vanden Bosch, F.A., \&Volberda, H. W. (2012). Offshoring and firm innovation: The moderating role of top management team attributes. Strategic Management Journal , 33 , 1480-1498.

Miller, D., \& Friesen, P. H. (1984). A Longitudinal Study of the Corporate Life Cycle. Management Science, 30 , 1161-1183. doi:10.1287/mnsc.30.10.1161.

Nelson, R. R. (2009). Routines as Technologies and as Organizational Capabilities. In M. Becker, \& N. Lazaric (Eds.), Organizational Routines: Advancing Empirical Research (pp. 11-25). Northampton, MA: Edward Elgar Publishing.

OECD (1999). Science, technology and industry scoreboard . Technical Report Organization for Economic Cooperation and Development (OECD).

O'Reilly, C.A., \& Tushman, M. L. (2008). Ambidexterity as a dynamic capability: Resolving theinnovator's dilemma. Research in Organizational Behavior, 28 , 185-206. doi:10.1016/j.riob.2008.06.002.

Pentland, B. T., Feldman, M. S., Becker, M. C., \& Liu, P. (2012). Dynamics of Organizational Routines: A Generative Model. Journal of Management Studies, 49 , 1484-1508. doi:10.1111/j.1467-6486.2012.01064.x.

Petter, S., Detmar, S., \& Arun, R. (2007). Specifying Formative Constructs in Information System Research. MIS Quarterly, 31 , 623-656. doi:10.1053/j. sult.2011.05.001.

Pezeshkan, A., Fainshmidt, S., Nair, A., Lance Frazier, M., \& Markowski, E. (2016). An empirical assessment of the dynamic capabilities-performance relationship. Journal of Business Research, 69 , 2950-2956. doi:10.1016/j. jbusres.2015.10.152. 
Podsakoff, P. M., MacKenzie, S. B., Lee, J. Y., \& Podsakoff, N. P. (2003). Common Method Biases in Behavioral Research: A Critical Review of the Literature and Recommended Remedies. Journal of Applied Psychology, 88 , 879-903. doi:10.1037/0021-9010.88.5.879. arXiv:arXiv:1011.1669v3.

Podsakoff, P. M., \& Organ, D. W. (1986). Self-Reports in Organizational Research: Problems and Prospects. Journal of Management , 12, 531-544.

Porter, M. E., Sala-i Martin, X., \& Schwab, K. (2012). The Global Competitiveness Report 2012-2013 . Technical Report World Economic Forum Geneva.

Raisch, S., \& Birkinshaw, J. (2008). Organizational ambidexterity: Antecedents, outcomes, and moderators. Journal of Management, 34, 375-409. doi:10. 1177/0149206308316058. arXiv:/dx.doi.org/10.5465/amj.2011.4000 FROM.

Ringle, C. M., Wende, S., \& Will, A. (2005). SmartPLS.

Sarkees, M., Hulland, J., \& Prescott, J. (2010). Ambidextrous organizations and firm performance: the role of marketing function implementation. Journal of Strategic Marketing , 18, 165-184.

Schilke, O. (2014). On the contingent value of dynamic capabilities for competitive advantage: The nonlinear moderating effect of environmental dynamism. Strategic Management Journal , 35 , 179-203.

Sinclair, G., Klepper, S., \& Cohen, W. (2000). What's Experience Got to Do With It? Sources of Cost Reduction in a Large Specialty Chemicals Producer. Management Science, 46, 28-45.

Sirmon, D. G., Hitt, M. A., \& Ireland, R. D. (2007). Managing Firm Resources in Dynamic Environments to Create Value: Looking inside the Black Box. The Academy of Management Review , 32 , 273-292.

Smith, K. G., Grimm, C. M., Gannon, M. J., \& Chen, M.-J. (1991). Organizational Information Processing, Competitive Responses, and Performance in the U.S. Domestic Airline Industry. The Academy of Management Journal , 34 , 60-85.

Song, M., Droge, C., Hanvanich, S., \& Calantone, R. (2005). Marketing and technology resource complementarity: An analysis of their interaction effect in two environmental contexts. Strategic Management Journal , 26, 259-276. doi:10.1002/smj.450.

Teece, D. (2007). Explicating dynamic capabilities: the nature and microfoundations of (sustainable) enterprise performance. Strategic Management Journal , $28,1319-1350$.

Teece, D. J. (2012). Dynamic Capabilities: Routines versus Entrepreneurial Action. Journal of Management Studies, 49 , 1395-1401. doi:10.1111/j. 14676486.2012.01080.x. arXiv:1. 
Teece, D. J. (2014). The Foundations of Enterprise Performance: Dynamic and Ordinary Capabilities in an (Economic) Theory of Firms. Academy of Management Perspectives, 28 , 328-352. doi:10.5465/amp.2013.0116. arXiv:z0024.

Teece, D. J., Pisano, G., \& Shuen, A. (1997). Dynamic capabilities and strategic management. Strategic Management Journal, 18, 509- 533. doi:10.1002/(SICI)1097-0266(199708)18:7<509::AID-SMJ882>3.0. CO;2-Z. arXiv:z0024.

Thompson, J. D. (1967). Organizations in action. New York: McGraw-Hill.

Tourangeau, R., Rips, L. J., \& Rasinski, K. (2000). The psychology of survey response. Cambridge: Cambridge University Press.

Trichterborn, A., Knyphausen-Aufseß, D. Z., \& Schweizer, L. (2015). How to improve acquisition performance: The role of a dedicated M\&A function, M\&A learning process, and M\&A capability. Strategic Management Journal , 37 , 763-773.

Tushman, M. L., \& Nadler, D. A. (1978). Information processing as an integrating concept in organizational design. Academy of Management Review , 3 , 613-624.

Upadhya, C., \& Vasavi, A. R. (2006). Work, Culture and Sociality in the Indian IT Industry: A Sociological Study.

Vinet, L., \& Zhedanov, A. (2010). A “missing” family of classical orthogonal polynomials. Journal of marketing research, 18 , 39-50. arXiv:1011.1669.

Vorhies, D. W., Morgan, R. E., \& Autry, C. W. (2009). Product-market strategy and the marketing capabilities of the firm: impact on market effectiveness and cash flow performance. Strategic Management Journal , 30, 1310-1334.

Wang, C. L., Senaratne, C., \& Rafiq, M. (2015). Success traps, dynamic capabilities and firm performance. British Journal of Management, 26, 26-44. doi:10.1111/1467-8551.12066.

Winter, S. G. (2003). Understanding dynamic capabilities. Strategic Management Journal , 24 , 991-995. doi:10.1002/smj.318. arXiv:z0023.

Zahra, S. A., Sapienza, H. J., \& Davidsson, P. (2006). Entrepreneurship and dynamic capabilities: a review, model and research agenda. Journal of Management Studies, 43 , 917-955.

Zhou, Z., \& Wu, F. (2010). Technological capability, strategic flexibility, and product innovation. Strategic Management Journal , 31 , 547-561.

Zollo, M., \& Winter, S. G. (2002). Deliberate Learning and the Evolution of Dynamic Capabilities. Organization Science, 13, 339-351. 
Table 1 The sample profile

\begin{tabular}{|c|c|c|c|}
\hline \multicolumn{2}{|c|}{$\begin{array}{l}\text { Firm composition (\%) } \\
\text { Industry }\end{array}$} & \multicolumn{2}{|l|}{$\begin{array}{l}\text { Respondent composition (\%) } \\
\text { Business Function }\end{array}$} \\
\hline Electronics & 26.54 & Commercial function & 10.00 \\
\hline IT & 61.54 & Technical function & 12.08 \\
\hline Biotechnology & 11.92 & $\begin{array}{l}\text { General/Strategic function* } \\
\text { Other (Finance and HR) function }\end{array}$ & $\begin{array}{r}70.83 \\
7.08\end{array}$ \\
\hline Firm Size & & Tenure in firm & \\
\hline$<49$ employees & 28.85 & $<3$ year & 15.19 \\
\hline 50-99 employees & 16.92 & $3-5$ years & 27.85 \\
\hline 100-249 employees & 20.00 & $6-10$ years & 25.74 \\
\hline 250-499 employees & 10.38 & $11-15$ years & 13.50 \\
\hline 500-999 employees & 8.85 & $\geq 16$ years & 17.72 \\
\hline $1,000-4,999$ employees & 10.00 & & \\
\hline$\geq 5$, oooemployees & 5.00 & & \\
\hline Firm age & & Ienure in Industry & \\
\hline$<5$ years & $17 \cdot 31$ & $\leq 6$ year & 11.02 \\
\hline 5-9 years & 20.00 & $6-10$ years & 14.83 \\
\hline 10-15 years & 22.69 & $11-15$ years & 17.80 \\
\hline $16-29$ years & 31.54 & $16-29$ years & 41.10 \\
\hline$\geq 30$ years & 8.46 & $\geq 30$ years & 15.25 \\
\hline
\end{tabular}

* These include top managers such as CEOs, founders, owners, partners, chairpersons, and managing directors who have more general or strategic function in a firm 
Table 2 Constructs

\begin{tabular}{|c|c|c|}
\hline \multicolumn{2}{|c|}{ Ordinary Marketing capability } & \multirow{2}{*}{$\begin{array}{r}\text { Loading } \\
0.84\end{array}$} \\
\hline OrdMar1 & Brand reputation or company image. & \\
\hline OrdMar2 & Distribution channels or sales force. & 0.88 \\
\hline OrdMar3 & Advertising/promotion resources or skills. & 0.89 \\
\hline \multicolumn{3}{|c|}{ Ordinary Technological capability } \\
\hline OrdTec 1 & Technological expertise. & 0.91 \\
\hline OrdTec2 & Technical skills and resources. & 0.95 \\
\hline OrdTec3 & Engineering and/or scientific skills and resources. & 0.91 \\
\hline \multicolumn{3}{|c|}{ Dynamic Marketing capability } \\
\hline DynMar1 & Assessing the potential of new markets. & 0.79 \\
\hline DynMar2 & Building relationships in new markets. & 0.83 \\
\hline DynMar3 & Setting up new distribution channels. & 0.77 \\
\hline DynMar4 & Setting up a new sales force. & 0.79 \\
\hline DynMar5 & Researching new competitors and new customers. & 0.69 \\
\hline \multicolumn{3}{|c|}{ Dynamic Technological capability } \\
\hline DynTec1 & Learning about technology it has not used before. & 0.89 \\
\hline DynTec2 & Assessing the feasibility of new technologies. & 0.88 \\
\hline DynTec3 & $\begin{array}{l}\text { Recruiting engineers and/or scientists in technical } \\
\text { areas it is not familiar with. }\end{array}$ & 0.60 \\
\hline DynTec4 & Identifying promising new technologies. & 0.89 \\
\hline \multicolumn{3}{|c|}{ Firm Efficiency } \\
\hline Effic1 & Profitability & 0.88 \\
\hline Effic2 & Return-on-assets (ROA) & 0.91 \\
\hline Effic3 & Return-on-investment (ROI) & 0.91 \\
\hline Effic4 & Return-on-sales (ROS) & 0.88 \\
\hline \multicolumn{3}{|c|}{ Firm Growth } \\
\hline Effect1 & Sales growth & 0.94 \\
\hline Effect2 & Growth in market share & 0.95 \\
\hline \multicolumn{3}{|c|}{ Environmental Turbulence } \\
\hline Env1 & $\begin{array}{l}\text { The actions of local and foreign competitors in our } \\
\text { major markets change quite rapidly. }\end{array}$ & 0.82 \\
\hline Env2 & $\begin{array}{l}\text { Technological changes in our industry are rapid and } \\
\text { unpredictable. }\end{array}$ & 0.78 \\
\hline Env3 & $\begin{array}{l}\text { The market competitive conditions are highly } \\
\text { unpredictable. }\end{array}$ & 0.85 \\
\hline Env4 & Customers' product preferences change quite rapidly. & 0.82 \\
\hline Env5 & Changes in customers' needs are quite unpredictable. & 0.76 \\
\hline
\end{tabular}


Table 3 Descriptive statistics of first-order factors

\begin{tabular}{|c|c|c|c|c|c|c|c|c|c|c|c|c|}
\hline & Mean & SD & Cronbach's $\alpha$ & $\mathbf{C R}$ & AVE & $\mathbf{A}$ & $\mathbf{B}$ & $\mathbf{C}$ & $\mathbf{D}$ & $\mathbf{E}$ & $\mathbf{F}$ & $\mathbf{G}$ \\
\hline Ordinary Marketing (A) & 4.82 & 1.17 & 0.84 & 0.90 & 0.76 & $0.87^{*}$ & & & & & & \\
\hline Ordinary Technological (B) & $5 \cdot 79$ & 0.99 & 0.91 & 0.95 & 0.85 & 0.36 & 0.92 & & & & & \\
\hline Dynamic Marketing (C) & 5.21 & 0.98 & 0.83 & 0.88 & 0.60 & 0.62 & 0.39 & 0.78 & & & & \\
\hline Firm Efficiency (E) & 5.15 & 1.14 & 0.92 & 0.94 & 0.80 & 0.49 & 0.34 & 0.41 & 0.22 & 0.90 & & \\
\hline Firm Growth (F) & 5.06 & 1.22 & 0.88 & 0.94 & 0.89 & 0.49 & 0.36 & 0.49 & 0.31 & 0.60 & 0.94 & \\
\hline Environmental turbulence (G) & 4.85 & 1.17 & 0.87 & 0.90 & 0.65 & 0.18 & 0.14 & 0.18 & 0.15 & 0.15 & 0.06 & 0.81 \\
\hline
\end{tabular}

Note SD: standard deviation. Cronbach's alpha with a cut-off point of 0.7 (Nunnally, 1978). CR: composite reliability with a cut-off point of 0.7 (Fornell and Larcker, 1981). AVE: average variance extracted with a cut-off point of 0.5 (Fornell and Larcker, 1981). 7-point Likert scales are used.

* Diagonal value in correlation matrix depicts square root of AVE, and off-diagonal value is correlations with other constructs. The former is greater than the latter in the same row and column (as recommended by Hair et al., 2010). 